\title{
Low effectiveness of inducing beta cell mass destruction as a model of type 1 diabetes on murine model by Streptozotocin infusion
}

\author{
Michal Wszola ${ }^{1}$, Marta Klak ${ }^{1}$, Anna Kosowska ${ }^{2}$, Grzegorz Tymicki ${ }^{1}$, Andrzej Berman ${ }^{1}$, Anna Adamiok-Ostrowska ${ }^{3}$, \\ Joanna Olkowska-Truchanowicz ${ }^{4}$, Izabela Uchrynowska-Tyszkiewicz ${ }^{4}$, Artur Kaminski $^{4}$

\footnotetext{
${ }^{1}$ Foundation of Research and Science Development, Foundation of Research and Science Development, Warsaw, Poland

${ }^{2}$ Department of Histology and Embryology, Medical University of Warsaw, Warsaw, Poland

${ }^{3}$ Department of Biochemistry and Molecular Biology, Centre of Postgraduate Medical Education, Warsaw, Poland

${ }^{4}$ Department of Transplantology and Central Tissue Bank, Medical University of Warsaw, Warsaw, Poland
}

Background: Type 1 diabetes (T1D) is an autoimmune disease leading to the loss of over $90 \%$ of the $\beta$-cells mass. Studies to assess the effectiveness of potential therapies are often conducted in a mouse model with chemically induced T1D. Predominantly, streptozotocin (STZ) is employed for this purpose. It is selective for $\beta$-cells and causes preferential accumulation in $\beta$-cells after entry through the GLUT 2 receptor and destruction of cells. This study aims to determine whether this model of T1D leads to the destruction of over $90 \%$ of $\beta$-cells when using different STZ induction protocols.

Methods: The studies were carried out on BALB/c mice. Groups differed in the STZ dose or the method of administration. Dosages ranging from 140-400 mg kg-1 have been tested. Controls were performed for 21 days. Immunohistochemical staining of pancreatic, kidneys and liver were performed and the body weight of animals was monitored.

Results: Dose $<300$ mg kg-1 cannot effectively destroy over $90 \%$ of the beta-cells mass. Despite high glucose levels, C-peptide levels were high. There were only two variants of STZ administration where animals were the destruction of beta-cell mass was considered as over $90 \%$. STZ dose of 300 and $400 \mathrm{mg} \mathrm{kg}-1$ reduced concentration of C-peptide to the values $<0.6 \mathrm{ng} / \mathrm{mL}$. Unfortunately, mortality in those groups was $100 \%$ within 2 weeks after induction of diabetes. Histological analysis showed damage of pancreatic islets and changes both in the glomeruli and liver tissue.

Conclusions: STZ is not an efficient method for induction of diabetes with over $90 \%$ destruction of beta cells in the murine model. C-peptide concentration should be considered as the most reliable indicator for diabetes diagnosis. $100 \%$ mortality in highSTZ groups is due to general inflammation of internal organs but not due to high glucose levels.

Corresponding author: Michal Wszola

E-mail: michal.wszola@fundacjabirn.pl

\section{(c) The Korean Society for Transplantation}

This is an Open Access article distributed under the terms of the Creative Commons Attribution Non-Commercial License (http://creativecommons.org/licenses/by-nc/4.0/) which permits unrestricted non-commercial use, distribution, and reproduction in any medium, provided the original work is properly cited. 